\title{
СУБЪЕКТЫ АДМИНИСТРАТИВНОЙ ЮРИСДИКЦИИ В АДМИНИСТРАТИВНОМ И АДМИНИСТРАТИВНО-ПРОЦЕССУАЛЬНОМ ЗАКОНОДАТЕЛЬСТВЕ
}

\section{SUBJECTS OF ADMINISTRATIVE JURISDICTION IN ADMINISTRATIVE AND ADMINISTRATIVE - PROCEDURAL LEGISLATION}

I. Zueva

Summary. At present, a considerable number of scientific works have been written by scientists - administrators, affecting the definition of subjects of administrative jurisdiction and their legal status, as indicated in administrative and administrative - procedural legislation. Various approaches to the definitions of a concept have been formed - the subject of administrative jurisdiction, administrative jurisdiction. Many authors believe that it is already overdue, considering the creation of a separate administrative and judicial system with the allocation of clearly formulated powers, rights and obligations governing the activities of subjects of administrative jurisdiction. Starostin S. A., noted "on the need to create administrative courts, or an independent, separate system." The article will address the definition of the subject of administrative jurisdiction, administrative jurisdiction, problems of creating administrative courts, conciliation procedures.

Keywords: subject of administrative jurisdiction, administrative jurisdiction, administrative proceedings, conciliation proceedings, administrative court, administrative dispute.
$\mathbf{K}$ оличество рассмотрения судебными органами административных производств, в настоящее время, к сожалению, не уменьшилось. Можно, констатировать, увеличение безграмотного правового самосознания граждан, бездействия юридических лиц, пробелы административного законодательства, низкую просветительскую работу должностных лиц, нарушение законодательства при проведении проверочных мероприятий и др. Обратимся к некоторой статистике рассмотрения количества административных производств, судами общей юрисдикции, мировых судов за 2018, 2019 год [14].

Статистика показывает, что не обходится административное производство без такого факта, как прекращение административного производства или его пересмотра, что говорит о некачественной проведенной процессуальной процедуре рассмотрения административных
Зуева Ирина Борисовна

Аспирант, Тихоокеанский государственный университет

zueva_irina44@mail.ru

Аннотация. В настоящее время немалое количество научных трудов написано учеными - административистами, затрагивающих определение субъектов административной юрисдикции и их правового положения, обозначенного в административном и административно - процессуальном законодательстве. Сформировались различные подходы к определениям понятия - субъект административной юрисдикции, административная юрисдикция. Многие авторы, считают, что уже назрело, рассмотрение вопроса о создании отдельной административно- судебной системы с выделением четко сформулированных полномочий, прав и обязанностей регулирующих деятельность субъектов административной юрисдикции. Старостин С. А., отметил «0 необходимости создания административных судов, либо самостоятельной обособленной системы». В статье будет затронуто определение субъекта административной юрисдикции, административной юрисдикции, проблемы создания административных судов, примирительные процедуры.

Ключевые слова: субъект административной юрисдикции, административная юрисдикция, административное производство, примирительные процедуры, административный суд, административный спор.

дел, либо в отсутствие профессиональной компетенции государственного органа в лице должностного лица при процедурном оформлении материалов административного дела.

Салищева Н.Г, писала «одним из основных элементов правового государства является институт судебного контроля за деятельностью органов исполнительной власти. Именно специфика этой деятельности, носящей подзаконный характер, порождает необходимость контроля со стороны представительных, вышестоящих в порядке подчиненности, а также судебных органов [15].

Автором, были исследованы, многие работы ученых административистов, в настоящее время, не сформировано единого подхода по определению понятия субъекта административной юрисдикции, административная юрисдикция. В научных трудах представлены разные 
Таблица. 1 Статистика рассмотрения количества административных производств, судами общей юрисдикции, мировых судов за 2018, 2019 год

\begin{tabular}{|l|l|l|}
\hline $\begin{array}{l}\text { Поступило административных производств в суды } \\
\text { общей юрисдикции. }\end{array}$ & 69056 & 68917 \\
\hline Оставлено без рассмотрения & 5918 & 6938 \\
\hline $\begin{array}{l}\text { Отменено с прекращением административно } \\
\text { призводства }\end{array}$ & 5414 & 4635 \\
\hline Возращено на новое рассмотрение & 4299 & 3531 \\
\hline $\begin{array}{l}\text { Оставлено без изменения решений судов } \\
\text { нижестоящих инстанций }\end{array}$ & 40800 & 395714 \\
\hline
\end{tabular}

мнения, но общий подход по мнению автора, определенно исходит к тому, что это субъект права, который наделен, полномочиями, правами и обязанностями по рассмотрению дел об административных правоотношениях.

Автор Гридин С.И., отметил «по общему правилу под административной юрисдикцией понимают компетенцию в рассмотрении тех или иных дел и принятие по ним решений» [3].

Авторы, Попов Л.Л, Студеникина М.С., определяют, «под административной юрисдикцией понимается нормативно урегулированная деятельность уполномоченных органов и должностных лиц по рассмотрению и разрешению в установленной законом административно-процессуальной форме административно правовых споров, вытекающих из административных правоотношений, и применению мер административного принуждения» [11].

Еще в 30-е годы прошлого столетия, Бродович С.М. писала, «обеспечение правильного применения мер административного воздействия является в настоящих условиях весьма важной политической задачей, так как административные взыскания служат мощным дисциплинирующим средством, но перегибов быть не должно» [1].

При совершении лицом, административного правонарушения, не возникает сразу же административный спор, он возникает только тогда, когда применяются те или иные санкции при выявленном правонарушении, с которыми лицо не согласно. Для разрешения административно спора, необходимо реализовать данный правовой механизм защиты через административную юрисдикцию управленческого органа или судебного.

В советский период, субъектами административной юрисдикции, были ведомства, местные исполкомы и советы. Автор, Бродович С. М., пишет «столь широкая и разнообразная сфера применения штрафов и связан- ная этим множественность органов, их налагающих, при слабом надзоре со стороны прокуратуры за правильностью действий этих органов и недостаточной регламентацией в законе оснований и порядка наложения штрафов способствовали появлению перегибов и извращений штрафной политики [2].

Автор, Осипова, О.В., отмечает, «субъект административной юрисдикции является центральным звеном правоприменителей законодательства об административной ответственности, только ему предоставлено право рассматривать дела об административных правонарушениях и принимать решения по ним» [10].

Сафоненков, П.Н, отметил «субъекты административно-юрисдикционной деятельности осуществляют юрисдикционные полномочия в пределах установленных нормативными правовыми актами полномочий. Для многих из них непосредственное участие в осуществлении административной юрисдикции ограничивается разрешением административно-правовых споров, возникающих в результате обжалования гражданами и организациями действий или правовых актов подчиненных им исполнительных органов и должностных лиц» [16].

Упорядочение видов и полномочий субъектов административной юрисдикции, было обозначено Указом Президиума Верховного совета СССР от 21 июня 1961года № 154/3 «О дальнейшем ограничении применения штрафов, налагаемых в административном порядке» [22]. Данным Указом, отменили наложение штрафов в административном порядке на учреждения, предприятия и организации, определили перечень органов с полномочиями, налагать административные штрафы.

В дальнейшем, согласно принятого Кодекса РСФСР об административных правонарушениях» утверждённым ВС РСФСР 20.06.1984, разделом III, закрепили правое определение перечня органов уполномоченных рассматривать дела об административных правонарушениях [7]. 
Попов Л.Л, отметил «в настоящее время можно говорить не о системе органов административной юрисдикции, наделенных полномочиями по рассмотрению дел об административных правонарушениях, а об их определенной совокупности, представленной в виде законодательно установленных перечней» [11].

Отличительная позиция была отмечена автором, Никифоровым М.В., «основным субъектом административной юрисдикции является у нас все-таки представители не судебной, а исполнительной власти. Значимость административных процедур очевидна, ибо их регламентация является непременным условием правомерности управленческих действий и результативности определяющего назначения государственного - управленческой деятельности в целом» [9].

Сафоненков П.Н., в тоже время отмечает «административная юрисдикция, тем не менее, не является исключительной прерогативой субъектов исполнительной власти. Значительная роль в ее осуществлении отводится органам судебной власти» [16].

Автор Миронов, А.Н пишет «государственные органы могут выступать в процессе как инстанция, разрешающая дело, и как сторона административного спора» [8].

Конечно, бесспорно, для юрисдикционно-административной деятельности, главные принципы - это законность, гласность, презумпция невиновности, объективность истины, равенство граждан перед законом, самостоятельность в принятии решения, ответственность должностных лиц за надлежащее ведение дела, обеспечения, привлекаемому к ответственности права на защиту, индивидуального наказания и т.д.

В настоящее время, главой 22 КоАП РФ определены субъекты административной юрисдикции, это судьи и органы по рассмотрению и разрешению административных дел административного производства, с определённым объёмом полномочий, территории, и т.д. Также имеется разделение на федеральный и региональный уровень. Субъекты административной юрисдикции - административные коллеги и административные комиссии (Закон Приморского края от 05 марта 2007 года № 44 -К3 «Об административных правонарушениях», [4] который определяет полномочия, права и обязанности этих органов, или определяющий перечень органов согласно Закона Приморского края от 06 октября 2015 года № 672-К3 «О перечне должностных лиц органов исполнительной власти Приморского края, уполномоченных составлять протоколы об административных правонарушениях при осуществлении регионального государственного контроля (надзора), государственного финансового контроля, а также пе- реданных полномочий в области федерального государственного надзора (с изменениями на 26 декабря 2019 года)) [5].

Перечень и объем полномочий органов и должностных лиц, на которые возложена обязанность рассматривать дела об административных правонарушениях закреплены в главе 23 КоАП РФ.

Как отметил автор Колоколов Н.А «значительная часть споров возникает в виде нежелания органов исполнительной власти надлежащим образом исполнять свои обязанности, своевременно регламентируя развитие правоотношений» [6].

Субъект административной юрисдикции, обладает, полномочиями, правами и осуществляет юридические обязанности в области рассмотрения дел об административных правонарушениях.

Хотелось, бы еще отметить, что в настоящее время, можно отнести к субъектам административной юрисдикции, и судебного примирителя, он независим и осуществляет свою деятельность самостоятельно, без участия судьи, в производстве которого находится дело. Сегодня сложно представить, развитие медиации в административном производстве.

Панкова О.В., отмечала «современное правосудие по делам об административных правонарушениях не имеет каких-либо институтов, которые открывали бы возможности для использования примирительных процедур между правонарушителем и жертвой, и с точки зрения основных задач, ориентиров и подходов по существу является карательным, нацеленным на доказывание виновности лица, привлекаемого к административной ответственности, и определения ему наказания в меру содеянного» [20].

Согласно статье 137 КАС РФ примирение сторон возможно при соблюдении определенных условий. Так, примирение может касаться только прав и обязанностей сторон как субъектов спорных публичных правоотношений и возможно только в случае допустимости взаимных уступок сторон.

Как сказано, в Постановлении Верховного суда от 31 октября 2019 г. N41, использование судебного примирения осуществляется для реализации таких задач судопроизводства, как мирное урегулирование споров, содействие становлению и развитию партнерских деловых отношений, формированию обычаев и этики делового оборота, оно может проводиться на любой стадии судебного процесса и при исполнении судебного акта [21]. 
Пунктом 2 ст. 24 вышеназванного Регламента, указано что результатом судебного примирения является заключение мирового соглашения, соглашения о примирении.

Автор, полагает, законодателю необходимо, предложить механизм, рассмотрения досудебного урегулирования спора, путем проведения примирительных процедур в рамках рассмотрения административного дела. Создать примирительные комиссии, прописать полномочия и компетенцию комиссии и должностного лица, разработать регламент, создающий правовой механизм рассмотрения примирительных процедур, закрепленных за государственным органом.

Президент в своем обращении к Федеральному собранию в 2003 году отметил «следует сформировать эффективно работающий механизм разрешения споров между гражданином и государством за счет совершенствования административных процедур и судебных механизмов» [13].

Как отметили, авторы Майоров В.И., Денисенко В.И. «административные суды должны позиционироваться в качестве самостоятельной ветви судебной власти, со своей организованной структурой, компетенцией и особым порядком рассмотрения подведомственных дел» [8].

Старилов Ю.Н. писал «совершенствование судебной системы должно происходить, главным образом, путем учреждения в стране административных судов. Речь идет о целесообразности учреждения в России административных судов, которые смогли бы более эффективно (по сравнению с нынешним уровнем и качеством судебной защиты, порядком работы государственных органов и должностных лиц) обеспечивать законность деятельности органов исполнительной власти, а также надежно защищать права, свободы и законные интересы физических и юридических лиц» [18].
Тема по созданию, административных судов, дискуссируется на протяжении многих лет, так и не нашла поддержки, в 2013 году Государственная Дума отклонила законопроект, предложенный Верховным судом РФ, поставив точку в этом вопросе[19].

При создании административных судов, во-первых, возникнет финансовая нагрузка на государство, во-вторых, в условиях сегодняшнего времени, необходимо дополнительно финансировать формирование качественного онлайн - правосудия в том числе и в административном производстве. Создание административных судов, не поможет скорректировать проблемы административного производства рассмотрения дел, исключить формальный подход к рассмотрению и повысить компетенцию судей и т.д.

Автор, предполагает, что возможно продолжить реформирование существующей судебной системы: передать рассмотрение вопросов о проверке законности решений и действий органов государственной власти и местного самоуправления, из арбитражных судов в суды общей юрисдикции (вопросы антимонопольного законодательства, транспортной безопасности, оспаривания предписаний природоохранного и санитарного законодательства и др.), с мировых судей часть дел по административным правонарушениям за невыполнение в срок законного предписания должностными лицами передать на рассмотрение органам, так как юридическое лицо имеет предметную связь с должностным лицом при рассмотрении административного дела.

Создать коллегиальные комиссии, которые могли бы рассматривать возникшие спорные публично - правовые отношения путем досудебного урегулирования административного спора, в процессуальное законодательство внести обязательный порядок досудебного урегулирования спора в вязи с примирением сторон, пересмотреть сроки на обжалование, что бы в запасе было время на обращения в суд.

\section{ЛИТЕРАТУРА}

1. Бродович С. М. Объединение законодательства об административных взысканиях / С. Бродович // За социалистическую законность.— М., 1935.— № 1 (январь).— - . 33, https://naukaprava.ru

2. Бродович С.М., о штрафах, налагаемых в административном порядке / Бродович // За социалистическую законность.— М., 1934. — № 10 (октябрь).c 11, https://naukaprava.ru

3. Гридин С.И., Административная юрисдикция в российском праве [Электронный ресурс] // Вестник Университета имени 0. Е. Кутафина (МГЮА) 2014.№ 2.- - c. 74 //lib.rucont.ru

4. Закон Приморского края «06 административных правонарушениях в Приморском крае (с изменениями на 8 апреля 2020 года)» $44-К 3$ от 05 марта 2007 г, «Ведомости Законодательного Собрания Приморского края», 06.03.2007, N10, http://docs.cntd.ru

5. Закон Приморского края от 06 октября 2015 года № 672-К3 «0 перечне должностных лиц органов исполнительной власти Приморского края, уполномоченных составлять протоколы 06 административных правонарушениях при осуществлении регионального государственного контроля (надзора), госу- 
дарственного финансового контроля, а также переданных полномочий в области федерального государственного надзора (с изменениями на 26 декабря 2019 года), «Ведомости Законодательного Собрания Приморского края», 07.10.2015, N135, c. 8-10. http://docs.cntd.ru

6. Колоколов Н.А., статья: В поисках регламента судебного примирения // Мировой судья. 2020. N1., c. 9-15. http://www.consultant.ru

7. Кодекс РСФСР 06 административных правонарушениях утв. ВС РСФСР 20.06.1984, «Свод законов РСФСР», т. 8, c. 401 // http://www.consultant.ru.

8. Миронов, А. Н. Административное право: учебник / А. Н. Миронов. — -е изд., перераб. и доп.— Москва: ИД «ФОРУМ»: ИНФРА-М, 2020.— - 122

9. Никифоров, М.Е., Административно-правовые споры в судах общей юрисдикции: автореферат дис. ... кандидата юридических наук: 12.00 .14 / Рос. акад. гос. службы при Президенте РФ.—- Москва, 2004.—c. 16-17 https://www.rsl.ru

10. Осипова 0.В., Субъекты административной юрисдикции: автореферат дис. ... кандидата юридических наук: 12.00.14 / Всерос. науч.-исслед. ин-т МВД PФ.—- Москва, 2004. — c. 9 https://search.rsl.ru

11. Попов, Л. Л. Административное право: Учебник / Под ред. Л. Л. Попова, М. С. Студеникиной — 2-е изд., перераб и доп. — Москва: Юр. Норма, НИЦ иНФPA-M, 2019.—с. 610, текст: электронный.—URL: https://znanium.com.

12. Попов, Л. Л. Административное право: Учебник / Под ред. Л. Л. Попова, М. С. Студеникиной — 2-е изд., перераб и доп.— Москва: Юр. Норма, НИЦ ИНФPA-M, 2019.—c. 274, текст: электронный.—URL: https://znanium.com.

13. Президент, Послание Федеральному Собранию Российской Федерации 16 мая 2003 года, http://kremlin.ru

14. Судебный департамент При Верховном суде РФ, «Отчет о работе судов общей юрисдикции по рассмотрению дел об административных правонарушениях» формы 1-АП, разделы 6,7 за 2018, 2019 г, http://www.cdep.ru

15. Салищева, Н. Г. Избранное [Электронный ресурс].— Москва: РАП, 2011.— С. 391, Текст: электронный._ URL: https://znanium.com.

16. Сафоненков, П. Н. Административная юрисдикционная деятельность: Учебное пособие / Сафоненков П. Н.— Москва: ИЦ РИОР, НИЦ ИНФРА-М, 2017., С. 8, https://znanium.com)

17. Сафоненков, П. Н. Административная юрисдикционная деятельность: Учебное пособие / Сафоненков П. Н.— Москва: ИЦ РИОР, НИЦ ИНФРА-М, 2017.С. 9. текст: электронный.—URL: https://znanium.com

18. Старилов, Ю.Н. Административное судопроизводство в Российской Федерации: развитие теории и формирование административно-процессуального законодательства. — Сер.: Юбилеи, конференции, форумы. — Вып. 7 [Электронный ресурс] / Ю. Н. Старилов. — Воронеж: Изд-во Воронежского государственного университета, 2013.- - . 287, https://znanium.com

19. Постановление Государственной Думы Федерального собрания РФ N2358-6 ГД от 11 июня 2013 года о проекте федерального конституционного закона № 7886-3 «0 федеральных административных судах в Российской Федерации». Собрание законодательства Российской федерации от 24.06 .2013 г № 25 ст. 3065, http://duma.gov.ru/

20. Панкова 0. В. Медиация в производстве по делам об административных правонарушениях: возможность или неизбежность? // Законы России: опыт, анализ, практика. 2019. N6., с. 81-84.

21. Постановлении Верховного суда от 31 октября 2019 г. N41, Бюллетень BC № 1 январь 2020// http://www.consultant.ru.

22. Указ Президиума Верховного совета СССР от 21 июня 1961 № 154/3 года «0 дальнейшем ограничении применения штрафов, налагаемых в административном порядке», Ведомости Верховного Совета СССР, N35, 1961, ст. 368. http://docs.cntd.ru

(с) Зуева Ирина Борисовна ( zueva_irina44@mail.ru ).

Журнал «Современная наука: актуальные проблемы теории и практики» 